\title{
Recent trends in publications in the European Journal of Epidemiology
}

\author{
Albert Hofman
}

Published online: 28 November 2008

(C) Springer Science+Business Media B.V. 2008

In this last issue of 2008 I take the opportunity to report some observations on recent trends in articles published in the EJE. In the first decade after Antonio Sanna founded the Journal in 1985 the emphasis was clearly on infectious diseases. Over half of the papers were in this category, and the methods papers generally also were on infectious diseases. This gradually changed after Claude Hannoun took over as editor-in-chief in 1995. He published a growing proportion of articles on chronic diseases, in particular cardiovascular disease. In recent years, the Journal has published increasingly papers on epidemiologic and statistical methods, on the objectives and study design of new epidemiologic studies, on genetic epidemiology, and on developmental epidemiology. Here I will review some of the highlights of the articles published in recent years, including those on infectious diseases.

Recent methods articles have addressed issues of measurement of determinants and outcome, exposuremeasurement error and information bias [1-10]. We have published some work on the design and evaluation of questionnaires, in particular on assessment of physical activity. We also have published important articles on causal modelling, on confounding, and on effect-modification and interaction.

In our section devoted to new studies the majority op articles has been on new birth cohort studies and other studies addressing early-life causes of adult diseases, and on the biobanks organized as part of those efforts [11-17].

In genetic epidemiology we have published some metaanalyses of candidate gene studies on various diseases, and

\footnotetext{
A. Hofman $(\bowtie)$

Department of Epidemiology, Erasmus Medical Center, P.O. Box 2040, 3000 CA Rotterdam, The Netherlands

e-mail: a.hofman@erasmusmc.nl
}

in the near future we will undoubtedly publish the results of the major genome-wide association studies that are currently underway in many epidemiologic research groups [18-22]. In addition, we have published commentaries on the value, of lack thereof, of predictive genetic testing for complex diseases and more in general on the promises of translational research in genomics.

We have published a substantial number of studies in developmental epidemiology, addressing fetal and other early life determinants of adult diseases [23-34]. This involved in particular studies of low birth weight and cardiovascular disease and diabetes, in different ethnic populations, and under different nutritional conditions. Increasingly, hemodynamic and endocrinological studies have addressed the hypothesis of early life causes of adult diseases. We have also published on the new studies in this field and on the epidemiologic resources that are now being build-up for future developmental epidemiologic studies.

The Journal publishes still a substantial number of articles on infectious diseases, about ten per cent of all published papers [35-55]. The largest number of articles in recent years has been on HIV/AIDS and on hepatitis, and quite often on their interrelations. We have also published work on new methods in infectious disease epidemiology, and on their applications to diseases like tuberculosis, malaria and meningitis. We will continue to emphasize the publication of important epidemiologic studies on infectious diseases in the Journal.

The EJE has become more selective over the years. In the first decade of its existence about half of the manuscripts that came to the office were published. In recent years this has gone down to about $15 \%$, reflecting both a substantially larger number of manuscripts received and a stricter acceptance policy. In this the editors have been strongly supported by the work for the Journal of many 
others. It is at place to thank all those involved in the European Journal of Epidemiology-authors, associate editors, editorial board members, the publisher and his dedicated staff-and in particular here the reviewers for the 2008 volume.

\section{A note of thanks}

The editors, members of the editorial board, and the publisher of the European Journal of Epidemiology wish to express their sincere gratitude to the referees of articles considered for the 2008 volume of the Journal.

\begin{tabular}{l} 
Lars Agreus \\
Thomas Ahern \\
Elaheh Ainy \\
Alvaro Alonso \\
Andrea Altieri \\
Rachel Bakker \\
Heejung Bang \\
Pascale Barberger-Gateau \\
Marie-Louise Bartelink \\
Heiko Becher \\
Klaus Berger \\
Anita Berglund \\
Eric Boersma \\
Luc Bonneux \\
Michiel Bots \\
Stefan-Martin Brand-Herrmann \\
Michael Bretthauer \\
Lex Burdorf \\
Raffaella Buzzetti \\
Dante Caceres \\
Anne Carbonne \\
Basile Chaix \\
Dana Dabelea \\
Jean Dallongeville \\
Maaike Dirks \\
Moustapha Drame \\
Carole Dufouil \\
Roberto Elosua \\
Jean Philippe Empana \\
Jean Ferrieres \\
Edith Feskens \\
Val Gebski \\
Simona Giampaoli \\
Klaus Giersiepen \\
Maurice Giroud \\
Michael Gorin \\
Sidsel Graff-Iversen \\
Sander Greenland \\
Sue Halliday \\
\hline a
\end{tabular}

Tomas Hemmingsson

Lena Holm

Gang $\mathrm{Hu}$

Imre Janszky

Anthony Jorm

Eric Jougla

Edmond Kabagambe

John Kellett

Sven Knüppel

Marcel Kornitzer

Madelon W. Kroneman

Lewis Kuller

Kari Kuulasmaa

Carianne L'Abée

Iain Lange

Kevin Laupland

Duk-Hee Lee

Anette Linnersjo

Theodore Liou

David Llewellyn

Hans Lundstrom

Luc Lvanhees

Pedro Marques-Vidal

Miguel Ángel Martínez

Richard Matthews

Franco Merletti

Dennis Mook

Peter Nilsson

Staffan Nilsson

Anna Peeters

Rodney Pollitt

Manuel Posada

Finn Rasmussen

Hervé Richet

Lorenzo Richiardi

Tessa Roseboom

Jean Bernard Ruidavets

Ebru Salcioglu

Jonathan Samet

Annelli Sandbaek

Marie-Jo Saurel-Cubizolles

Gary Schwartz

Alex Smith

Harold Snieder

Andreas Stang

Eric Steegers

Regine Steegers

Lars C. Stene

Ewout Steyerberg

Theo Stijnen

Fabrizio Stracci

David Strachan

Sven Törnberg 
Dimitrios Trichopoulos

Ylva Trolle Lagerros

Ed van Beeck

Frits van Griensven

Tyler Vanderweele

Mechtild Vennemann

Tommy Visscher

Aline Wagner

Tim Waterboer

Hajo Zeeb

\section{References}

1. Schmidt ME, Slanger T, Chang-Claude J, Wahrendorf J, Steindorf K. Evaluation of a short retrospective questionnaire for physical activity in women. Eur J Epidemiol. 2006;21:575-85.

2. Orsini N, Bellocco R, Bottai M, Pagano M, Wolk A. Reproducibility of the past year and historical self-administered total physical activity questionnaire among older women. Eur J Epidemiol. 2007;22:363-8.

3. Jurek AM, Maldonado G, Greenland S, Church TR. Exposuremeasurement error is frequently ignored when interpreting epidemiologic study results. Eur J Epidemiol. 2006;21:871-6.

4. Tolonen H, Helakorpi S, Talala K, Helasoja V, Martelin T, Prattala R. 25-Year trends and socio-demographic differences in response rates: Finnish adult health behaviour survey. Eur J Epidemiol. 2006;21:409-15.

5. Iwasaki M, Yamamoto S, Otani T, Inoue M, Hanaoka T, Sobue T, et al. Generalizability of relative risk estimates from a welldefined population to a general population. Eur $\mathrm{J}$ Epidemiol. 2006;21:253-62.

6. Groenwold RH, Hoes AW, Hak E. Confounding in publications of observational intervention studies. Eur J Epidemiol. 2007; 22:413-5.

7. Flanders WD. On the relationship of sufficient component cause models with potential outcome (counterfactual) models. Eur J Epidemiol. 2006;21:847-53.

8. Ekman A, Dickman PW, Klint A, Weiderpass E, Litton JE. Feasibility of using web based questionnaires in large populationbased epidemiological studies. Eur J Epidemiol. 2006;21:103-11.

9. Richiardi L, Baussano I, Vizzini L, Douwes J, Pearce N, Merletti F. Feasibility of recruiting a birth cohort through the Internet: the experience of the NINFEA cohort. Eur J Epidemiol. 2007;22: 831-7.

10. Kallberg H, Ahlbom A, Alfredsson L. Calculating measures of biological interaction using R. Eur J Epidemiol. 2006;21: 571-3.

11. Danesh J, Saracci R, Berglund G, Feskens E, Overvad K, Panico $\mathrm{S}$, et al. EPIC heart: the cardiovascular component of a prospective study of nutritional, lifestyle and biological factors in 520, 000 middle-aged participants from 10 European countries. Eur J Epidemiol. 2007;22:129-41.

12. Hofman A, Breteler MM, van Duijn CM, Krestin GP, Pols HA, Stricker BH, et al. The Rotterdam Study: objectives and design update. Eur J Epidemiol. 2007;22:819-29.

13. Jaddoe VW, Mackenbach JP, Moll HA, Steegers EA, Tiemeier H, Verhulst FC, et al. The Generation R Study: design and cohort profile. Eur J Epidemiol. 2006;21:475-84.

14. Jaddoe VW, Bakker R, van Duijn CM, van der Heijden AJ, Lindemans J, Mackenbach JP, et al. The Generation R Study
Biobank: a resource for epidemiological studies in children and their parents. Eur J Epidemiol. 2007;22:917-23.

15. Clarisse B, Nikasinovic L, Poinsard R, Just J, Momas I. The Paris prospective birth cohort study: which design and who participates? Eur J Epidemiol. 2007;22:203-10.

16. Ronningen KS, Paltiel L, Meltzer HM, Nordhagen R, Lie KK, Hovengen R, et al. The biobank of the Norwegian Mother and Child Cohort Study: a resource for the next 100 years. Eur J Epidemiol. 2006;21:619-25.

17. Stolk RP, Rosmalen JG, Postma DS, de Boer RA, Navis G, Slaets $\mathrm{JP}$, et al. Universal risk factors for multifactorial diseases: Lifelines: a three-generation population-based study. Eur J Epidemiol. 2008;23:67-74.

18. Pereira TV, Rudnicki M, Pereira AC, Pombo-de-Oliveira MS, Franco RF. Do polymorphisms of 5, 10-methylenetetrahydrofolate reductase (MTHFR) gene affect the risk of childhood acute lymphoblastic leukemia? Eur J Epidemiol. 2006;21:885-6.

19. Zintzaras E, Koufakis T, Ziakas PD, Rodopoulou P, Giannouli S, Voulgarelis M. A meta-analysis of genotypes and haplotypes of methylenetetrahydrofolate reductase gene polymorphisms in acute lymphoblastic leukemia. Eur J Epidemiol. 2006;21:501-10.

20. Cottone M, Renda MC, Mattaliano A, Oliva L, Fries W, Criscuoli $\mathrm{V}$, et al. Incidence of Crohn's disease and CARD15 mutation in a small township in Sicily. Eur J Epidemiol. 2006;21:887-92.

21. Portoles O, Sorli JV, Frances F, Coltell O, Gonzalez JI, Saiz C, et al. Effect of genetic variation in the leptin gene promoter and the leptin receptor gene on obesity risk in a population-based case-control study in Spain. Eur J Epidemiol. 2006;21:605-12.

22. Janssens AC, van Duijn CM. Towards predictive genetic testing of complex diseases. Eur J Epidemiol. 2006;21:869-70.

23. Jaddoe VW, Witteman JC. Hypotheses on the fetal origins of adult diseases: contributions of epidemiological studies. Eur $\mathrm{J}$ Epidemiol. 2006;21:91-102.

24. Silva AA, Mehta Z, O'Callaghan FJ. Duration of breast feeding and cognitive function: population based cohort study. Eur $\mathbf{J}$ Epidemiol. 2006;21:435-41.

25. Vos LE, Oren A, Bots ML, Gorissen WH, Grobbee DE, Uiterwaal CS. Birth size and coronary heart disease risk score in young adulthood. The Atherosclerosis Risk In Young Adults (ARYA) study. Eur J Epidemiol. 2006;21:33-8.

26. Pollitt RA, Kaufman JS, Rose KM, Diez-Roux AV, Zeng D, Heiss G. Early-life and adult socioeconomic status and inflammatory risk markers in adulthood. Eur J Epidemiol. 2007;22: $55-66$.

27. Lawlor DA, Cooper AR, Bain C, Davey Smith G, Irwin A, Riddoch $\mathrm{C}$, et al. Associations of birth size and duration of breast feeding with cardiorespiratory fitness in childhood: findings from the Avon Longitudinal Study of Parents and Children (ALSPAC). Eur J Epidemiol. 2008;23:411-22.

28. Tu YK, Manda SO, Ellison GT, Gilthorpe MS. Revisiting the interaction between birth weight and current body size in the foetal origins of adult disease. Eur J Epidemiol. 2007;22:565-75.

29. Koupil I, Shestov DB, Sparén P, Plavinskaja S, Parfenova N, Vågerö D. Blood pressure, hypertension and mortality from circulatory disease in men and women who survived the siege of Leningrad. Eur J Epidemiol. 2007;22:223-34.

30. Olsen SF, Østerdal ML, Salvig JD, Kesmodel U, Henriksen TB, Hedegaard M, et al. Duration of pregnancy in relation to seafood intake during early and mid pregnancy: prospective cohort. Eur J Epidemiol. 2006;21:749-58.

31. Geleijnse JM, Witteman JC, Stijnen T, Kloos MW, Hofman A, Grobbee DE. Sodium and potassium intake and risk of cardiovascular events and all-cause mortality: the Rotterdam Study. Eur J Epidemiol. 2007;22:763-70.

32. Nabet C, Lelong N, Ancel PY, Saurel-Cubizolles MJ, Kaminski M. Smoking during pregnancy according to obstetric 
complications and parity: results of the EUROPOP study. Eur $\mathbf{J}$ Epidemiol. 2007;22:715-21.

33. Strandberg-Larsen K, Rod Nielsen N, Nybo Andersen AM, Olsen J, Grønbaek M. Characteristics of women who binge drink before and after they become aware of their pregnancy. Eur J Epidemiol. 2008;23:565-72.

34. Gravseth HM, Bjerkedal T, Irgens LM, Aalen OO, Selmer R, Kristensen P. Life course determinants for early disability pension: a follow-up of Norwegian men and women born 1967-1976. Eur J Epidemiol. 2007;22:533-43.

35. Tomaso H, Mooseder G, Dahouk SA, Bartling C, Scholz HC, Strauss R, et al. Seroprevalence of anti-Yersinia antibodies in healthy Austrians. Eur J Epidemiol. 2006;21:77-81.

36. de Greeff SC, Spanjaard L, Dankert J, Hoebe CJ, Nagelkerke N, de Melker HE. Underreporting of meningococcal disease incidence in the Netherlands: results from a capture-recapture analysis based on three registration sources with correction for false positive diagnoses. Eur J Epidemiol. 2006;21:315-21.

37. Christensen PB, Kringsholm B, Banner J, Thomsen JL, Cowan S, Stein GF, et al. Surveillance of HIV and viral hepatitis by analysis of samples from drug related deaths. Eur J Epidemiol. 2006;21:383-7.

38. Deuffic-Burban S, Costagliola D. Including pre-AIDS mortality in back-calculation model to estimate HIV prevalence in France, 2000. Eur J Epidemiol. 2006;21:389-96.

39. Magoni M, Alberto M, Signorini Liana S, Donato Francesco D. Do environmental factors influence the occurrence of acute meningitis in industrialized countries? An epidemic of varying aetiology in northern Italy. Eur J Epidemiol. 2006;21:465-8.

40. Gerlich M, Gschwend P, Uchtenhagen A, Krämer A, Rehm J. Prevalence of hepatitis and HIV infections and vaccination rates in patients entering the heroin-assisted treatment in Switzerland between 1994 and 2002. Eur J Epidemiol. 2006;21:545-9.

41. Eveillard M, Lancien E, de Lassence A, Branger C, Barnaud G, Benlolo JA, et al. Impact of the reinforcement of a Methicillinresistant Staphylococcus aureus Control Programme: a 3-year evaluation by several indicators in a French University Hospital. Eur J Epidemiol. 2006;21:551-8.

42. Chatzipanagiotou S, Economou M, Papavasileiou C, Ioannidis A, Ioannidou V, Papavasileiou E, et al. Incidence of bacterial and viral enteric pathogens in children with gastroenteritis over a one year-period, in Attica, Greece. Eur J Epidemiol. 2006;21: $613-4$.

43. Kourbatova EV, Leonard MK Jr, Romero J, Kraft C, del Rio C, Blumberg HM. Risk factors for mortality among patients with extrapulmonary tuberculosis at an academic inner-city hospital in the US. Eur J Epidemiol. 2006;21:715-21.
44. Guerrin-Tran E, Thiolet J-M, Rousseau C, Henry S, Poirier C, Che D, et al. An evaluation of data quality in a network for surveillance of Mycobacterium tuberculosis resistance to antituberculosis drugs in Ile-de-France region-2001-2002. Eur J Epidemiol. 2006;21:783-5.

45. Ioannidis A, Nicolaou C, Legakis NJ, Ioannidou V, Chatzipanagiotou $\mathrm{S}$. The first database comprised of flagellin gene (flaA) types of Campylobacter jejuni human clinical isolates from Greece. Eur J Epidemiol. 2006;21:823-9.

46. Kohl I, Němeček V, Summerová MR, Chlíbek RK, Nad'ová K, Mináriková O. Long-term protective effect of post-exposure Havrix $^{\mathrm{TM}}$ administration during viral hepatitis Type A outbreaks. Eur J Epidemiol. 2006;21:893-9.

47. Locquet C, Marande JL, Choudat D, Vidal-Trecan G. Hepatitis B vaccination in women healthcare workers: a seroepidemiological survey. Eur J Epidemiol. 2007;22:113-9.

48. Lobacheva T, Asikainen T, Giesecke J. Risk factors for developing tuberculosis in remand prisons in St Petersburg, Russia-a case-control study. Eur J Epidemiol. 2007;22:121-7.

49. Quoilin S, Hutse V, Vandenberghe H, Claeys F, Verhaegen E, De Cock L, et al. A population-based prevalence study of hepatitis A, $\mathrm{B}$ and $\mathrm{C}$ virus using oral fluid in Flanders, Belgium. Eur J Epidemiol. 2007;22:195-202.

50. Saadatian-Elahi M, Mekki Y, Del Signore C, Lina B, Derrough T, Caulin E, et al. Seroprevalence of varicella antibodies among pregnant women in Lyon-France. Eur J Epidemiol. 2007;22:405-9.

51. Davidovici BB, Balicer RD, Klement E, Green MS, Mendelson E, Smetana Z, et al. Comparison of the dynamics and correlates of transmission of Herpes Simplex Virus-1 (HSV-1) and Varicella-Zoster Virus (VZV) in a sample of the Israeli population. Eur J Epidemiol. 2007;22:641-6.

52. Deuffic-Burban S, Losina E, Wang B, Gabillard D, Messou E, Divi N, et al. Estimates of opportunistic infection incidence or death within specific CD4 strata in HIV-infected patients in Abidjan, Côte d'Ivoire: impact of alternative methods of CD4 count modelling. Eur J Epidemiol. 2007;22:737-44.

53. Syrjänen K, Shabalova I, Petrovichev N, Kozachenko V, Zakharova T, Pajanidi J, et al. Smoking is an independent risk factor for oncogenic human papillomavirus (HPV) infections but not for high-grade CIN. Eur J Epidemiol. 2007;22:723-35.

54. Camoni L, Salfa MC, Regine V, Pasqualini C, Borghi V, Icardi $\mathrm{G}$, et al. HIV incidence estimate among non-nationals in Italy. Eur J Epidemiol. 2007;22:813-7.

55. Lake IR, Harrison FC, Chalmers RM, Bentham G, Nichols G, Hunter PR, et al. Case-control study of environmental and social factors influencing cryptosporidiosis. Eur J Epidemiol. 2007;22: 805-11. 